\title{
SYMBOLIC CONSTRUCTION OF NATIONAL IDENTITY: A QUALITATIVE ANALYSIS OF NGOS INSTAGRAM POSTS ON NATIONAL DAYS
}

\author{
Umur BEDİR \\ İstanbul Aydın University, Turkey \\ umurbedir@aydin.edu.tr \\ https://orcid.org/0000-0002-6313-4028 \\ Müge ÖZTUNÇ \\ İstanbul Aydın University, Turkey \\ mugeoztunc@aydin.edu.tr \\ https://orcid.org/0000-0002-4514-7386
}

\begin{tabular}{|l|l|}
\hline \multirow{3}{*}{ Atıf } & $\begin{array}{l}\text { Bedir, U. ve Öztunç, M. (2022). SYMBOLIC CONSTRUCTION OF NATIONAL } \\
\text { IDENTITY: A QUALITATIVE ANALYSIS OF NGOs INSTAGRAM POSTS ON } \\
\text { NATIONAL DAYS. The Turkish Online Journal of Design Art and Communication, 12 (1), } \\
\text { 192-211. }\end{array}$ \\
\hline
\end{tabular}

\begin{abstract}
This article examines how NGOs representing social groups in Turkey symbolically construct national identity by describing national days on Instagram. National signs and symbols function to communicate national identity to its members and create a sense of belonging. Visual images also appear as traces of social, economic, and political processes in which identities are shaped. Therefore, this paper argues that analyzing Instagram posts by NGOs can provide insight into how national identity is constructed through national days. NGOs' organization fields are chosen considering the 2018 report of 'NGOs in the Development Process' by the Turkish Ministry of Development, and the 'maximum diversity sampling' method was used for analysis. A grounded coding process supported a thematic analysis approach was used to explore how NGOs portray national days. For this qualitative thematic analysis, a coding frame was used to conduct cluster analyses of the symbols using QDA Miner software to understand how they relate. The findings indicate that the celebration messages are mostly visualized through certain national symbols in social media. These differ in three main national identity discourses (Kemalist Nationalism, Right-Conservatism, Liberal-Kemalism and small segment of Islamist discourse and Turkism discourse shaped around nationalism, militarism and partly Islamism) parallel to NGO's political and ideological positions or social groups and values they represent.
\end{abstract}

Keywords: Communication Studies, Instagram, National Days, National Identity, Symbolic Construction.

\section{ULUS KIMLİĞİNİN SEMBOLİK İNŞASI: STK'LARIN ULUSAL GÜNLERDEKİ INSTAGRAM PAYLAŞIMLARININ NITEL ANALIZİ}

ÖZ

$\mathrm{Bu}$ makale Türkiye'de farklı toplumsal grupları temsil eden sivil toplum kuruluşlarının (STK) Instagram'daki ulusal bayram temsilleri üzerinden ulus kimliğini sembolik olarak nasıl inşa ettiklerini incelemektedir. Ulusal simge ve semboller, ulusal kimliği iletme ve aidiyet duygusu inşa etme işlevi

Research Article - This article was checked by iThenticate Copyright (C) The Turkish Online Journal of Design, Art and Communication 
üstlenirler. Görsel imgeler, aynı zamanda kimliklerin şekillendiği sosyal, ekonomik ve politik süreçlerin izleri olarak ortaya çıkar. Bu bağlamda, makalede STK'ların Instagram gönderilerini analiz etmenin, ulusal kimliğin ulusal günler aracılığıyla nasıl inşa edildiğine dair fikir verebileceği savunulmaktadır. STK'ların örgütlenme alanları, Türkiye Kalkınma Bakanlığı'nın '2018 Kalkınma Sürecindeki STK'lar' raporu dikkate alınarak seçilmiş ve analiz için 'maksimum çeşitlilik örneklemesi' yöntemi kullanılmıştır. STK'ları milli bayramlar üzerinden tanımlamak amacıyla gömülü kodlama süreci kullanılarak tematik içerik analiz yöntemi uygulanmıştır. QDA Miner yazılımı kullanılarak kodların birbirleri ile ne şekilde ilişkilendiğini ortaya çıkarmak amacıyla kümeleme analizinden yararlanılmıştır. Bulgular, kutlama mesajlarının çoğunlukla sosyal medyadaki belirli ulusal semboller aracıllğıyla görselleştirildiğini ve bunların, STK'ların siyasi ve ideolojik pozisyonlarına veya temsil ettikleri sosyal gruplara ve değerlere paralel olarak üç ana ulusal kimlik söylemi (Kemalist-Milliyetçi, Muhafazakar-Sağ, Liberal-Kemalist söylem ve daha küçük bir kümede İslamcı söylem ve Türkçü söylem) çerçevesinde farklılaştığını göstermektedir.

Anahtar Kelimeler: Instagram, İletişim Çalışmaları, Sembolik İşa, Ulusal Günler, Ulusal Kimlik.

\section{INTRODUCTION}

It can be challenging to agree on the definition, functions, and characteristics of national identity which can be considered the ultimate presentation of collective belonging that builds modern societies. This difficulty is due to the extensive academic literature available that extends their focus beyond the boundaries of national identity. Furthermore, national identity is a dynamic, structured concept that has assumed various meanings and contents in different countries throughout history. According to Smith (1991: 14), a national identity assumes certain conditions, such as "a historic territory or homeland, common myths, and historical memories, a mass and public culture, a common economy, and common legal rights and duties" for all members. National identity relies on the resources of history, language, and culture to create a reference point that determines the collective belonging of its members and draws the boundaries between "us" and "the other". National identity also takes on the function of legitimizing and reflecting the institutions and existing power relations in the society in question. On the other hand, all sorts of community claims and forms of collective identity, including national identity, are constructed by/through symbols whose meanings and contents change depending on historical conditions and social groups that refer to them.

This study focuses on the symbolic and visual representation of Turkish national identity. It also focuses on non-governmental organizations (NGOs) that operate in different areas and from different social and ideological backgrounds. Presently, NGOs exert influence in many public spheres, including the economy, politics, culture, and social life. These organizations, which have expanded their influence in Turkey in recent times, are considered as one of the most critical sources of power next to financial institutions, multinational companies, and the media (Canbolat, 2002: 9). Although the effectiveness of civil society in Turkey and the extent to which it acts from a rights-based perspective are often questioned, these organizations can also be positioned as tools of the struggle for hegemony between different ideologies and political movements in Turkey (Ayan, 2019;148). The symbols that NGOs share on social media in official national days and which ones they highlight and in what kind of framework they present them, appear as guiding elements in the reinterpretation of national identity through symbols. Within the scope of the research, 38 NGOs from different fields of activity and with different ideological backgrounds were included in the sampling by purposive sampling method. How these NGOs interpreted national identity differed in four national holidays; The Commemoration of Atatürk, Youth and Sports Day (May 19), National Sovereignty and Children's Day (April 23), the Republic Day of Turkey (October 29), and Victory Days also known as Turkish Armed Forces Day (August 30) were examined by thematic analysis method on their Instagram posts. The research project, which follows a thematic analysis, covers four official national days in Turkey during 2019. 


\section{Literature Review}

Current literature draws attention to the fact that national identity - unlike other identities - is not natural and given but constructed and artificial (Hall, 1996; Hobsbawm and Ranger, 2000; Anderson, 2006; Edensor, 2002; Wodak, 2009; Skilling, 2010). Anderson regards nations (and all other communities larger than face-to-face groups) as imagined communities. Furthermore, national identity-which ascribes itself to a political unity and sovereignty that is composed of the sum of individuals and further claims a shared historical and cultural collectivity-is neither a reality nor an awakening to selfconsciousness, but a discursive and mental construct (Anderson, 2006).

A state's discursive authority enables it to impose fixed ideas through symbols and discourses about who does and who does not belong to the nation. Although it is stated that national identity is not natural, this, strongly connected to and influenced by existing power relations within a society (Skilling, 2010: 178). According to Laclau, "them" is constructed and even if all realities are universal, they appear as the result of political struggle for hegemony (Laclau, 2005). Reproduction of alternative symbols represents hegemonic cultural struggle as well. Such as identity discourses; Political, economic, social, and ideological dynamics can produce symbols that easily permeate daily practice. They are also based on (objective) historical, political, social, and economic contexts.

Because identities are built through discourse, Hall (1996: 4) argues that "we need to understand them as produced in specific historical and institutional sites within specific discursive formations and practices, by specific enunciative strategies." This reasoning paves the way for the content and meanings of a national identity to be redefined and articulated through various types of belonging over time. According to Wodak (2009: 16), the dynamic and flexible nature of national identity makes it impossible to talk about a pure and homogeneous identity - whether at an individual or collective level. Wodak (2009:16) further argues that "individuals as well as collective groups such as nations are in many respects hybrids of identity." Every nation-state contains fragments of social, ethnic, cultural, linguistic, religious, sexual, and political identities that at times clash with another. Furthermore, one or more of these multiple identities may dominate depending on the social, political, and economic changes and interactions specific to the period.

According to Cohen $(2001 ; 98)$ a community "is a symbolic construct rather than a structural one." Aside from accentuating common values and shared ideas that build a "we," a community's symbols also constitute the repertoire of meanings that individuals can refer to when defining their identities. Furthermore, communities use myth, ritual, and its heroes to construct a selective relationship between the present and the future (Cohen 2001: 99). Hofstede indicates that culture manifests itself in four different levels that can be illustrated "as the skins of an onion" (Hofstede 1991, 7): symbols, heroes, rituals, and values. Each "onion" has its clearly defined profile, similar to the national boundaries of politically defined and artificially created nation-states. Symbols such as flags, emblems, currency, capitals, anthems, and monuments all form a web of signification. Furthermore, these nations need such celebrations to legitimize existing power relations and inculcate certain values and behavior patterns through repetition. However, Hobsbawm and Ranger's approach has been criticized for assuming that the masses are recipients of these symbols and their ideological messages (Edensor, 2002). From this point of view, "these cultural productions achieve elite objectives in pacifying the masses and coercing them into line with the national project" (Edensor, 2002: 5). Importantly, however, symbolic cultural elements do not have entirely fixed meanings; in daily life and popular culture these elements can take on new meanings, and, depending on the conditions, individuals and social groups that make up the nation can attribute new meanings to symbols (Edensor, 2002: 6).

\section{The National Symbols that Shape National Identity in Turkey}

At the heart of the Republic of Turkey's national symbolism (including its national days) lie the national liberation struggle, the modernization processes, and the cult figure of national hero Atatürk. The national struggle started in 1919 when the Turkish nationalist resistance movement resisted the Allied powers' invasion of the Ottoman Empire and lasted until the establishment of the Republic of Turkey 
in 1923, after the War of Independence. This period remains a common theme of the official national holidays in Turkey. Themes, including the narratives of the national struggle and the Republic itself, often emphasize a national history independent of the Ottoman Empire. Originally, the symbols crowning these themes were amplified through a state-centric approach and functioned as carriers of stories of a shared national identity. It would, however, be a mistake to limit Turkey's national days to liberation narratives only. Modernization, which began to exert its influence intellectually and institutionally during the period of the Tanzimat (Alkan, 2001: 20), found its way not only into state bureaucracy but also into the daily lives of the people under the leadership of the Republic's founders who defined modernization as a national goal. Reforms (including democratic, industrial, and technological developments, the visibility of women in the public sphere, the new Latin alphabet, and Western-style clothing) in various spheres and the transformation of social and cultural institutions left their mark on the first decade of the Republic.

During the national struggle and early Republican periods, Atatürk (Caymaz, 2019), the hero of liberation and founder of modern Turkish Republic, was at the heart of the official historical narrative and national symbolism (Ökten, 2007). Kemalism, on the other hand, was central to the reforms. Researchers who criticize Kemalism regard the philosophy as an elitist, centralist, statist, and positivist ideology that forces people to Westernize (Parla, 1991; Robins, 1996; Zürcher, 1998). These criticisms are grounded in the center-periphery paradigm of Şerif Mardin (1973), which asserts that the center formed by the founding elites of the Republic imposed Westernization on those in the periphery; in other words, civil society and the conservative-religious. Those on the periphery reacted to this process by clinging to the existing traditional cultural structure. Although this approach regards the centerperiphery distinction in a culturally reductionist context, it would not be inaccurate to state that for a long time, Turkish politics have been organized on a polarized axis between a statist-elitist and an opposing conservative-liberal understanding (Kongar, 2013).

In Turkey, especially with the transition to a multi-party system in 1950, those who advocate more visibility of Islam and conservative symbols in the public sphere used right-wing political parties to get their requests on the public agenda (Keyman, 2007: 223). In a sense, this development marks the beginning of a widening gap between political views (Toprak and Çarkoğlu, 2006).

The 1960, 1971, and 1980 military coups, as well as the February 28, 1997 process (also referred to as the postmodern coup) are critical historical turning points that affect national symbolism. At the time of these events, the activities of movements that oppose the official national narrative and their political parties, press organs, or NGOs were restricted or ended. (These movements included Islamist, socialist, and ethnic groups.) In the public sphere, many symbols representing these ideologies, including the headscarf, were banned. At the same time, coup administrations and military elites intensely utilized symbols of Atatürk and placed great emphasis on Kemalism to gain social legitimacy (Aydoğan, 2011 and Cizre-Sakallığlu and Çınar, 2002). These actions have led to the perception that the emphasis on a Kemalist thought system and Atatürk affirms the dominant role of the army in Turkish politics (with tutelage).

The national symbols in Turkey have undergone several major transformations with the emergence of new identities. Identity politics, the economic and political liberalization, globalization, and the rise of the Islamist/conservative movement have paved the way for these changes. These social transformations of national symbols can be grouped into four interrelated categories: privatization, pluralization, commercialization, and miniaturization (Özyürek, 2004; Caymaz, 2019).

During the 1990s, Turkey witnessed the rise of new political and social movements that opposed the official national narrative and strengthened identity politics. The country's national identity symbols have multiplied, and Islamist conservatives perceived this as an opportunity. Consequently, top-down

\footnotetext{
${ }^{1}$ Unlike other coups, the military did not directly seize power in their attempt on February 28 but forced the government to resign by utilizing bureaucracy and the media. For this reason, the events of February 28, 1997, is referred to as the postmodern coup (Cizre-Sakallıgglu \& Çınar, 2002).
}

Research Article - This article was checked by iThenticate Copyright (C) The Turkish Online Journal of Design, Art and Communication 
approaches lost their power to address the complexity of the national audience and the heterogeneity of national discourses in Turkey (Skey, 2009: 336). However, social changes in the cultural sphere can potentially be manipulated by the capital owners, religious persons, politicians, and the media (just like the economic sphere is regulated by the powerful figures for their own interests), so it can be said that the media in Turkey has played a crucial role in mobilizing the Islamist movement. According to Caymaz (2019: 10), with the rise of the Islamist movement and the Justice and Development Party (the AKP), "official nationalism was being reframed within the context of a highly Islamized populist nationalism, Atatürk's figure as the unique and unifying national symbol weakened." Accordingly, various symbols of the Ottoman heritage were introduced into everyday life and political discourse (Ongur, 2015: 417), and, because of the media, this process was regarded as a liberation from the nationstate's authority that has opened the door for minority groups to voice their opinions and concerns (Appadurai 1996: 27-47; Castells 1997: 69; Keyman 1997: 193-206).

The intense deregulation of the media sector coincided with the establishment of the first private television and radio stations. Furthermore, because of the diversification and internationalization of audience experiences caused by the expansion of cable and satellite broadcasting in the 1990s, the existing, shared media and audience experiences were replaced with audience mobilization and fragmentation. In addition, the rise and increasing visibility of the Islamist/conservative movement in the 1990s promoted diversification among secular - moderns. Initially, the AKP repositioned a moderate alternative model against secular modernization and secular nationalism, and this approach has played a crucial role in the support it received from different segments of the society (Açıkel, 2015). However, with the policies pursued by the AKP after 2010, Kemalism ceased to be an official ideology and turned into an opposition discourse (Y1lmaz vd. 2020). This reactive stance has led to the more intensive and voluntary use and ownership of the national symbols referring to the values of the Republic and Atatürk by the social groups in question. People increasingly started to use national symbols (that were previously exhibited in public spaces, government buildings, and official celebrations) at their homes and in their daily lives and private spaces. Furthermore, parallel to this commercialization process of national symbols, individuals started to express their voluntary loyalty to the Republican reforms and their opposition to the Islamist/conservative government, secularism, and Atatürk through car stickers, tattoos, t-shirts, and other accessories. As a result, they distinguished themselves from the groups that did support these conservative movements (Özyürek, 2006; Caymaz, 2019; Hart, 1999).

During the early days of the Republic, Turkey's national symbols comprised grand and enduring visual elements such as gigantic architectural structures (Bozdoğan, 1997; Kezer, 2009), streets named after Atatürk and other heroes of the national struggle (Houston, 2005), bronze sculptures (Gur, 2013), as well as monuments (Meeker, 1997), paintings (Altan, 2004), and mausoleums (Glyptis, 2008). After the 1990s, against the nature of the nation-building efforts of the early Republican period, more implicit symbols and expressions found their way into the media, everyday life, and popular culture. Termed "Banal Nationalism" by Billig (2010), this phenomenon became more widespread (Köse and Y1lmaz, 2012; Yumul and Özkırımlı, 2000).

The privatization and pluralization of national symbolism in the 1990s were not limited to tangible signs. During the same period, national days (as an abstract way to remember and strengthen national identity) and how they were celebrated also changed (Billig, 2010: 57). McCrone and McPherson (2009: 1-3) point out that some countries - especially in multinational states - celebrate competing national days, which suggests that these celebrations are problematic and controversial. National days (as signs of national identity) are, therefore, not stable; they are discoverable, can take on new meanings over time, or may lose their validity altogether (Geisler, 2009). In Turkey, for example, the official national holidays were widely celebrated under the sponsorship of the state after the proclamation of the Republic and during the single-party era. Whereas the state initially planned official ceremonies, celebrations, and commemorations in a hierarchical manner, these were gradually replaced by voluntary celebrations initiated by non-state private actors, individuals, civil society, and even companies. Furthermore, commercials aired on national days by NGOs and private companies advocate a secularist perspective 
(such as TÜSİA ${ }^{2}$ ) and make an overwhelming impression on the public. The commercial of Sabanc1 group (one of the founders of TÜSİAD), has been published on October 29 2020, and made a gigantic impact by highlighting republican values such as women's rights, freedom of speech, science and development ${ }^{3}$. Through activities such as these, citizens and private organizations appear to have voluntarily and personally internalized republican principles even in those areas of everyday life that exist outside the state authority (Özyürek, 2006: 379).

With the transition to the multi-party system and the rise of political Islamism, alternative (or competing) national days emerged in addition to the official national holidays. The AKP government regarded the new national days - that were marked by a religious background or connection to the military victories of the Ottoman and Seljuk empires - as competition for the official national days. In recent years, conflict over official national days has entered public debates. The government's decision to ban stadium shows and place restrictions on the celebration of official national days on the grounds of terrorist attacks or the global Covid-19 pandemic frequently makes it onto the public agenda. These decisions are interpreted as Kemalism-centered ${ }^{4}$ initiatives that aspire to challenge the official national identity.

\section{Instagram as Medium of Visual Communication in the Age of Social Media}

In addition to mainstream media, the spread of digital media since the 1990s has significantly impacted identity politics in Turkey. Although some commentators argue that the internet and new communication technologies have downplayed locally based forms of collective belonging, including national identity, the Internet and new media technologies put forward local forms of collective belonging, including national identity, into the background (Poster, 1999; Mills, 2002; Bauman, 2008), the Internet creates a platform for different social segments where counter-publics can actively reproduce, interpret, challenge, and oppose the symbols of banal nationalism (Szulc, 2017; Baruh and Popescu, 2008). According to Castells, although new communication technologies support the process of individuation by reversing the traditional forms of community based on space, this is not the end of the community or locality (hence the nation). Instead, it reconstructs social relations by connecting online interaction with offline, cyberspace with local space $(2016 ; 10)$. The spread of social media has also partially supported the individualization and fragmentation of national discourse and symbolism (Gündüz and Erdem, 2017). Digitalization and social media's extensive technical possibilities allows individuals and social groups to manipulate national symbols by visually removing or transforming them into elements of social interaction through sharing. Instagram is a visual-based social media used extensively in Turkey, stands out as one of the channels where national symbols are produced and transmitted. (Marcella-Hood, 2019; Avedissian, 2016). It is also a playground for international and/or local subcultures and "cultural identities that established via small variations and differences" of themes, narration, visual styles and aesthetics. "Digital cameras and editing and publishing tools as exemplified by Instagram provide the crucial mechanism to further refine and 'individualize' these basic identities" (Manovich, 2017; 89-90).

Visual images are traces of social identities, processes, practices, experiences, institutions, and relationships (Khatib, 2013). Furthermore, visual images create the spaces in which social and political worlds are generated and identities are shaped. Abstract images become tangible through signs that provide clues about the history of these images. According to Barthes (1972), an object becomes a sign when it replaces another through convention and use. Symbols, rituals, and myths play a dominant role

\footnotetext{
2 The Turkish Industry and Business Association (TÜSİAD) is a voluntary, independent, non-governmental organization dedicated to promoting public welfare through private enterprise. It was founded in 1971. TÜSİAD defines itself as an organization dedicated to democracy, rules of the universal principles of human rights, and freedom of thought, belief, and enterprise. The organization is committed to developing a social structure that promotes the objectives set by Atatürk: reaching the level of contemporary civilizations and establishing a democratic civil society and a secular state of law (see https://tusiad.org/tr/tusiad/tuzuk).

${ }^{3}$ https://www.cumhuriyet.com.tr/video/sabancidan-ses-getiren-cumhuriyet-bayrami-filmi-1786634

${ }^{4}$ See https://www.duvarenglish.com/columns/2020/05/20/what-national-day-celebrations-tell-us-about-turkey.
}

Research Article - This article was checked by iThenticate Copyright (C) The Turkish Online Journal of Design, Art and Communication 
in the reconstruction of national identity. Myths are widely held false ideas that have taken on the form of traditional stories, and they carry meanings within certain structures. Barthes points out that dynamically structured myths can adapt to meet changing cultural needs. Messages are conveyed through form and meant to convince people to adopt a certain ideology (Barthes, 1972). Therefore, changes in the structure of a sign (or symbol) transform its meaning and, accordingly, the behavior it encourages a society to adopt.

National signs, traditions, and rituals are, in many respects, the most influential and enduring components of nationalism. They materialize the basic concepts of nationalism, make them visible to other members of society, and help to make abstract ideologies more tangible (Anderson, 2006). Shaped by a sense of shared loyalty toward symbols, nationalism also confirms that members of the community belong to the same society. In this sense, symbols posted on Instagram on national holidays (such as Atatürk, the flag, and images of children or war) can convey multiple meanings while also bearing social and political messages. How these signs are used (i.e., with what other visual elements they are paired with or whether they are used at all) is an important indicator of the intended message.

Turkey has 38 million Instagram users, which places the country at $6^{\text {th }}$ place globally (We Are Social Digital Report, 2020) ${ }^{5}$. Furthermore, Instagram relies heavily on visual imagery and, therefore, provides the ideal opportunity to thematically analyze the use of visual messages. In addition, the visual content on the platform is easily accessible, which makes it a lively and interactive platform that engages users. In this regard, Berger (1972) writes that "seeing comes before words." Visual imagery relies on lighting, color, background, composition, and visual rhetorical figures to better convey a message or explain the accompanying text. Even emotion, which is difficult to describe with text, can be conveyed more effectively through images (Rose, 2016). Rose (2016) further asserts that visual imagery has become an integral part of social life and offers us an opportunity to understand different views. Content creators and editors produce visual frames by selecting and combining various visual elements (Coleman, 2010; Hansen and Machin, 2013). The NGOs that represent various social groups and ideologies in Turkey produce such visual frames to maintain and construct national identity on Instagram.

\section{Research Design}

Semiotics is an investigation into how meaning is created and how meaning is communicated. Barthes indicates that "the viewer of the image receives at one and the same time the perceptual message and the cultural message" (Barthes, 1977, p. 36). It means that all visuals have functions, and they have communicative power, and images are never innocent (Aiello 2006). However, their messages often are naturalized by being associated with a given perceptual object. Visual texts differ from verbal texts, because they are communicative across cultural codes while also carrying culturally specific meanings. In analyzing images, it is necessary to account not only for their cultural norms, but also for their perceptual qualities. Semiotic analysis of images, open the way for critical approach and methodological standpoint of the article is to analyze images according to representation, interaction, composition, and organization (Iedema, 2001; Jewitt and Oyama, Aiello 2006).

The study's main objective is to analyze how different social groups in Turkey reconstruct and reinterpret the national symbols through NGOs' Instagram posts on national days. In order to identify tangible clusters, a grounded coding process was applied to 228 images shared in national days by 38 NGOs during 2019. QDA Miner software that permits to code and retrieves text or photos and store files in an internal database was used for the coding process. The software's primary function is content analysis, but it also offers a range of advanced features that allow for frequency and statistical analyses of textual or photographic data (Atherton and Elsmore, 2007; Mangabeira, Lee et all., 2004; Lapan 2013; Bazeley 2013). While this research is qualitative, this particular software-enabled cluster analysis is to be conducted to help understand how codes go together. The Jaccard similarity coefficient is a statistic used to understand the similarities between sample sets. As shown in (Figure 1), the codes were thus

\footnotetext{
${ }^{5}$ See https://wearesocial.com/digital-2020
} 
grouped into three main and other small clusters according to Jaccard's coefficient. Colors show the similarities, and the size of bars mention the size of codes. This method enabled identifying national symbols on each national day and helped to understand the similarities and differences of each category for interpretation.

\section{Sample Design}

The organizations included in the sample $\left(n=38^{6}\right)$ are chosen considering the 2018 report of 'NGOs in the Development Process' prepared by the Turkish Ministry of Development within the framework of the 'Eleventh Development Plan' covering the years 2019-2023 (Table:1). After determining the fields of activity, research sampling has been chosen by considering the ideological backgrounds of the NGOs. In this context, 'maximum diversity sampling that is one of the purposive sampling methods, was used for analyzing.

\begin{tabular}{lcc} 
VALUE & NGO & $\begin{array}{c}\text { TOTAL } \\
\text { PERCENT }\end{array}$ \\
Social Aid & 6 & $16 \%$ \\
Football Fun & 5 & $13 \%$ \\
Economy & 4 & $11 \%$ \\
Youth & 3 & $8 \%$ \\
Religious & 2 & $5 \%$ \\
Environmental & 2 & $5 \%$ \\
Political & 2 & $5 \%$ \\
Press & 2 & $5 \%$ \\
Think Tank & 2 & $5 \%$ \\
Education & 2 & $5 \%$ \\
Search Rescue & 1 & $3 \%$ \\
Historical Memory & 1 & $3 \%$ \\
Health & 1 & $3 \%$ \\
Human Rights & 1 & $3 \%$ \\
Arc Sport (Islamic) & 1 & $3 \%$ \\
Labour & 1 & $3 \%$ \\
Love Peace & 1 & $3 \%$ \\
Bicycle & 1 & $3 \%$ \\
\hline TOTAL & $\mathbf{3 8}$ & $\mathbf{1 0 0} \%$ \\
\hline
\end{tabular}

\section{Research Questions}

Table 1: Types of NGOs

For this qualitative thematic analysis, a coding frame was constructed and then used to conduct cluster analyses of the symbols and how they relate to another. This method has enabled the researchers to explore how symbols differ within the context of these structures. The following research questions (RQs) guided the research process:

RQ1: Considering the Instagram posts of NGOs in official national days, how do the meanings attributed to national identity differ?

RQ2: What visual elements and themes are commonly emphasized in the national day Instagram posts, and are these different for each holiday?

RQ3: How do NGOs differ in the context of national days they celebrate and not celebrate?

\section{Limitations}

This study offers patterns and interpretations of NGOs' Instagram posts, but these patterns cannot represent all fractions of national identity. While using these patterns, a quantitative segmentation analysis that represented Turkey and applied to the public (individuals) instead of NGOs can offer more fragments of national identity.

\footnotetext{
${ }^{6}$ AÇEV, AGD, AHBAP, AKUT, Alperen Ocakları, ASKON, Ateşböceği Derneği, Bisikletliler Derneği, Cansuyu, Cem Vakfi, Çarşı Beşiktaş, ÇGD, ÇYDD, Deniz feneri, Diyanet Vakfi, Doğa Derneği, Genç FB, HAYKOD, Hayvanları Koruma Derneği, IHD, KADEM, IHH, Kara Kutu, LÖSEV, MÜSİAD, Okçular Vakfi, SETA Vakfi, TEGV, TEMA, TOBB, Trabzonlu Gençler, TÜGVA, TÜRGEV, TÜSİAD, Ultra Aslan, Ülkü Ocakları, Uğur Mumcu AG Vakfı, Yeşil Düşünce Derneği.
} 


\section{Findings}

The analyses of the data indicate that the NGOs that did not post on these days (or did so only once) are predominantly Islamist-conservative, such as the Anatolian Youth Association (AGD), the Association of Anatolian Businessmen (ASKON), the Anatolian Lions Businessmen Association, the Turkish Religious Foundation, the Humanitarian Relief Foundation (IHH), the Youth of Trabzon, and the Football Fan Association. The analyses further suggest that organizations that posted visuals related to their field of activity only or did not make much use of their Instagram accounts include liberal NGOs such as the social aid association Ateş Böceği, the association for raising the awareness of youth against historical injustice (Karakutu), and the association for spreading green policies (Green Thought), as well as left-wing oriented NGOs, including the Labor Union and the Uğur Mumcu Investigative Journalism Foundation $^{7}$, the ÇGD, the Contemporary Journalists Association (IHD), and the Human Rights Association. The main visual elements used by the NGOs included in this study are Atatürk (including his signature, quotations, and symbols that refer to him indirectly), as well as images that represent the Republic, flag, national struggle, war, heroism and martyrdom, and youth and children. The NGOs used these symbols and visual elements in different contexts and in line with their fields of activity, worldviews, and ideologies to create different semantic patterns. For this reason, the above-mentioned themes (e.g., the flag and war, etc.) were interpreted in relation to the symbols present in the visuals shared by the NGOs.

\section{Cluster Analysis}

The sources that were coded similarly were clustered together, as shown in Figure 1. The codes were thus grouped into four clusters according to Jaccard's coefficient for cluster analysis. Figures $2-5$ show the visuals shared on the Instagram posts representing these clusters.

As the analysis indicates, some clusters differ significantly (see Figure 1). The first cluster of posts includes visuals about Atatürk's initiation of the national struggle when he set foot in Samsun, excerpts from his Great Speech (known as Nutuk), as well as images that emphasize the importance of progress in line with Atatürk and the Republic's basic principles. These posts, which focus on Atatürk as the founder of the Republic and the commander of the national struggle, position the youth as Atatürk's followers and the future of the country. Secular and Kemalist associations such as the Association for Supporting Contemporary Life (ÇYDD), the Beşiktaş football fan club that was active in the Gezi Park Protests (Çarşı Beşiktaş), the Search and Rescue Association (AKUT,) and the football fan club of Fenerbahçe (Genç Fenerbahçeliler) all shared this theme.

In another cluster of posts, Atatürk is shown in a military uniform, at the front line, and wearing a calpac ${ }^{8}$ (Figure 2, Nos. 1-2). Interestingly, the calpac - a symbol that emphasizes Atatürk's military identityis also noticeable in posts in which he wears civilian clothes. Generally, this eclectic use of symbols is more evident in the posts of liberal, liberal-conservative, and more institutionalized NGOs, such as the patterns have become standard for each national day. A consensus exists in using common symbols such as the flag, national struggle, Atatürk, martyrdom, republic, youth, and children. The findings show that NGOs in Turkey use common national symbols in combination with alternative symbols and reinterpret them within different contexts on their digital media platforms.

Turkish Union of Chambers and Commodity Exchanges (TOBB), the Turkish Youth and Education Services Foundation (TÜRGEV), and the Idealist Hearths

\footnotetext{
${ }^{7}$ The association was founded in the memory of the assassinated journalist Uğur Mumcu.

8 The calpac, (or the Caucasian or Cossack fur hat) protected riders in the harsh Anatolian weather and gradually became the symbol of the national resistance (Mango, 2002). In later years, several prominent members of the Committee of Union and Progress (the dominant political formation of the second Constitutional Period) participated in the National Forces Movement. The calpac became the symbol of these two movements (Türk, 2018). The photographs of Atatürk wearing a calpac, however, represent the national struggle in Turkish politics, the war of liberation, and the fight against imperialism.
} 


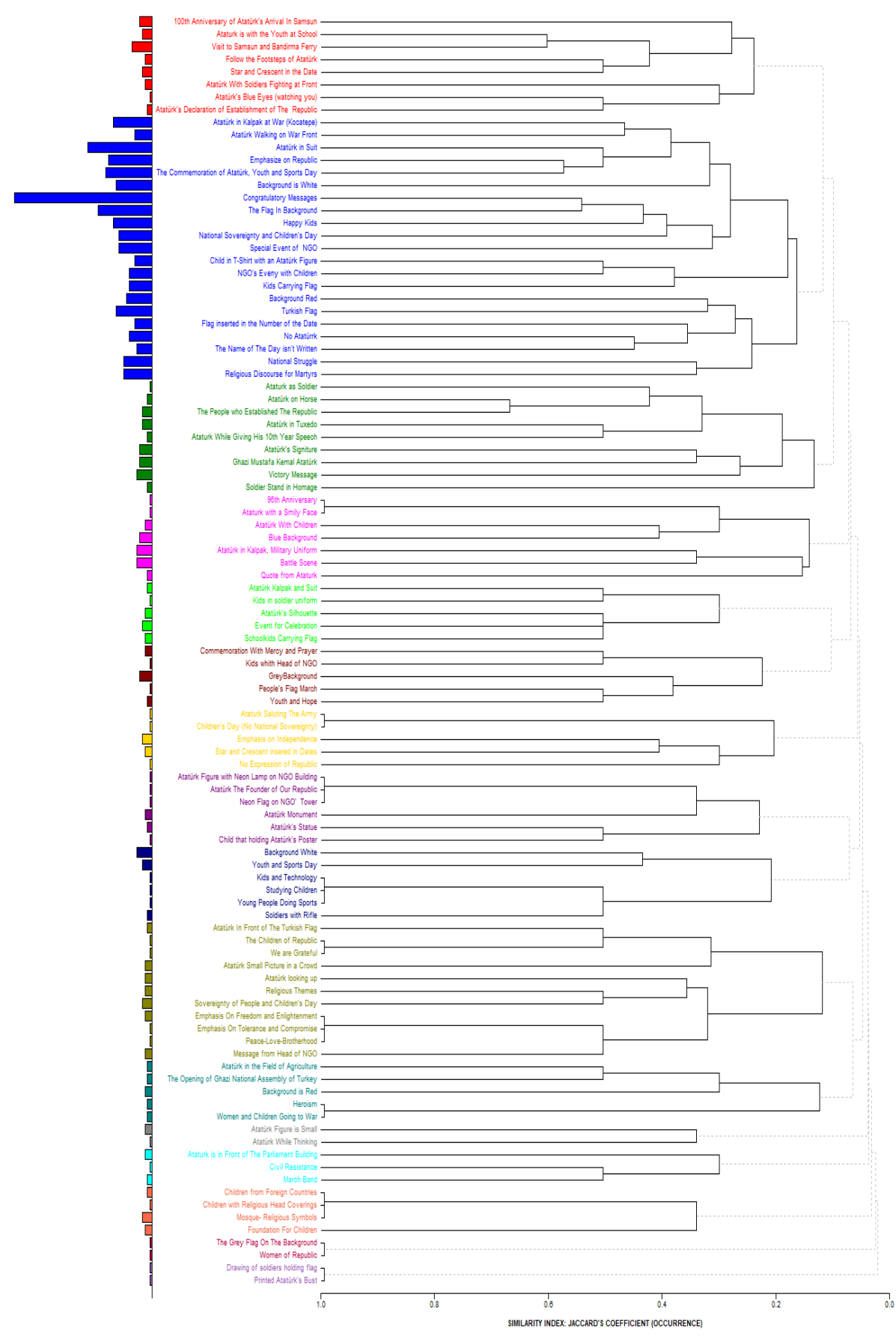

Figure 1: Cluster Analysis

In the segment, where celebration messages are also used extensively, there is a noteworthy difference between the NGOs' posts in terms of placing Atatürk at the center or excluding him entirely. Overall, a photograph of Atatürk that was taken during the great struggle was shared the most (Figure 2, No. 1). This photograph is considered one of the symbols of the victory of August 30, 1922 and associated with Atatürk's military achievements. It was taken by Etem Tem on the morning of the attack in Kocatepe and captures Atatürk wandering alone between the rocks in a pensive manner and with his thumb between his lips (Figure 2, No. 1). This iconic photograph was shared by NGOs that operate in different fields and with different ideologies. These include liberal-conservative NGOs, such as ASKON, the

Research Article - This article was checked by iThenticate 
Women and Democracy Association (KADEM), TOBB, the nationalist-conservative Idealist Hearths, as well as the secular NGOs the Search and Rescue Association, AKUT, TÜSİAD, UM-AG, the Uğur Mumcu Investigative Journalism Foundation, and ÇYDD. These NGOs also organized their own events to celebrate national days and tended to include children in their activities (Figure 3, No.4).

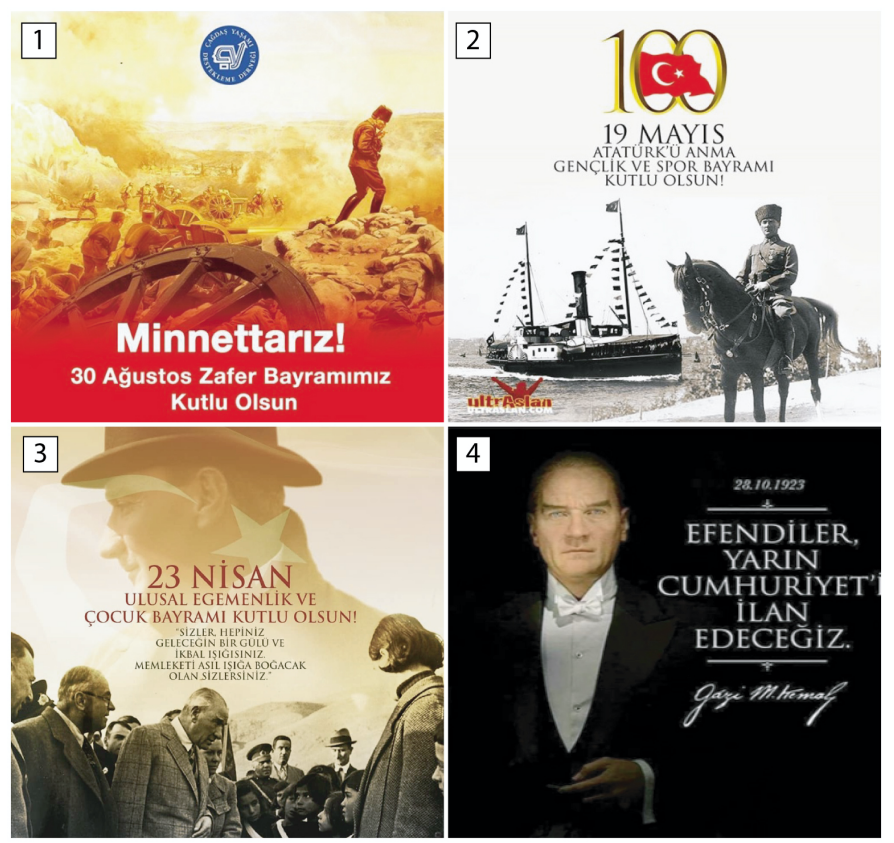

Figure 2: Instagram posts by ÇYDD, the GS Football Fan Club Ultra Aslan, and 3 and $4^{\text {th }}$ pictures belong to the Çarşı Besiktas Football Fan Club.

In posts with a similar theme but in which Atatürk was absent (Figure 3, Nos. 1-3), the Turkish flag was used prominently and, instead of portraying Atatürk as the head of the army, the images accentuated military service and martyrdom. This trend was noted in the posts of more liberalconservative NGOs (e.g., the Association of Independent Industrialists and Businessmen's Association [MÜSİAD ${ }^{9}$ ]) and Islamist-conservatives (e.g., the Cansuyu and Deniz Feneri social aid associations, the Turkish Youth Foundation [TÜGVA], and TÜRGEV) (Figure 3, Nos. 13). Notably, the NGOs that posted celebratory messages without giving full details about the specific day also did not include visuals of Atatürk in their posts.

The third cluster of codes show photographs of Atatürk that accentuate his contemporary and modern clothes (e.g., suits, a tuxedo, and a bow tie) (Figure 2, No. 4 and Figure 3, No. 4). His other accessories include hats, batons, gloves, ties, scarves, and pocket-handkerchiefs. These images, which show him in black suits or frock coats along with his signature and quotations from the Republic's $10^{\text {th }}$-anniversary speech, portray Atatürk as a leader and the founder of the Republic. The posts that shared this theme were presented against a blue corporate background. The posts of TÜSİAD, which express the NGO's commitment to the principles of the Republic and its legislation, are a reflection of the posts that were shared in this segment. Furthermore, these posts emphasized the flag and children and the youth. The posts stressed that young people and children carry us into the future and should, therefore, possess

\footnotetext{
${ }^{9}$ Based on religious values, MUSIAD was founded in 1990 within the global market and liberal economic model by the provincial conservative capital groups as an alternative to secularist TUSIAD. A small number of large and well-established companies, a limited number of multi-partner holdings that are newly developing in Anatolia, and many small and mediumsized enterprises (SMEs) came together in a religious and conservative identity perspective to form MUSIAD (Alkan, 1998; Öniş and Türem 2001: 100; Gümüşçü, 2010: 841).
}

Research Article - This article was checked by iThenticate Copyright (C) The Turkish Online Journal of Design, Art and Communication 
national consciousness and be equipped - mentally and physically — to address the challenges of our time.
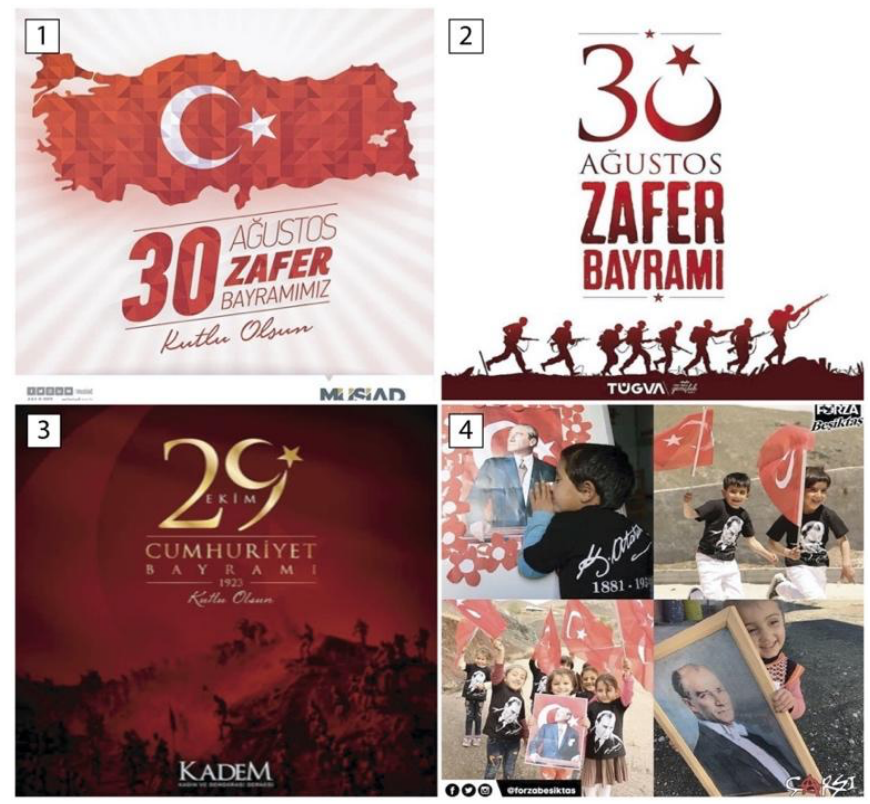

Figure 3: Instagram posts by MÜSİAD, TÜGVA, KADEM, and the Çarşı Besiktas Football Fan Club.

Posts of liberal-conservative NGOs such as TÜGVA, TÜRGEV, and KADEM (Figure 4) represent a small cluster of codes. These codes suggest that children and the youth engage in activities such as fitness, chess, and technology (Figure 4, No. 1). Unlike the other clusters, the posts in this cluster did not represent children as followers of Atatürk; rather, these posts emphasized the principles of the Republic against a mostly white background (Figure 4, Nos. 2-4). Noticeably, in this cluster too, the full names of the national days were not included. For example, instead of referring to the Commemoration of Atatürk/Youth and Sports Day, the posts would say only "19 May Youth and Sports Day" (Figure 4, No. 3).

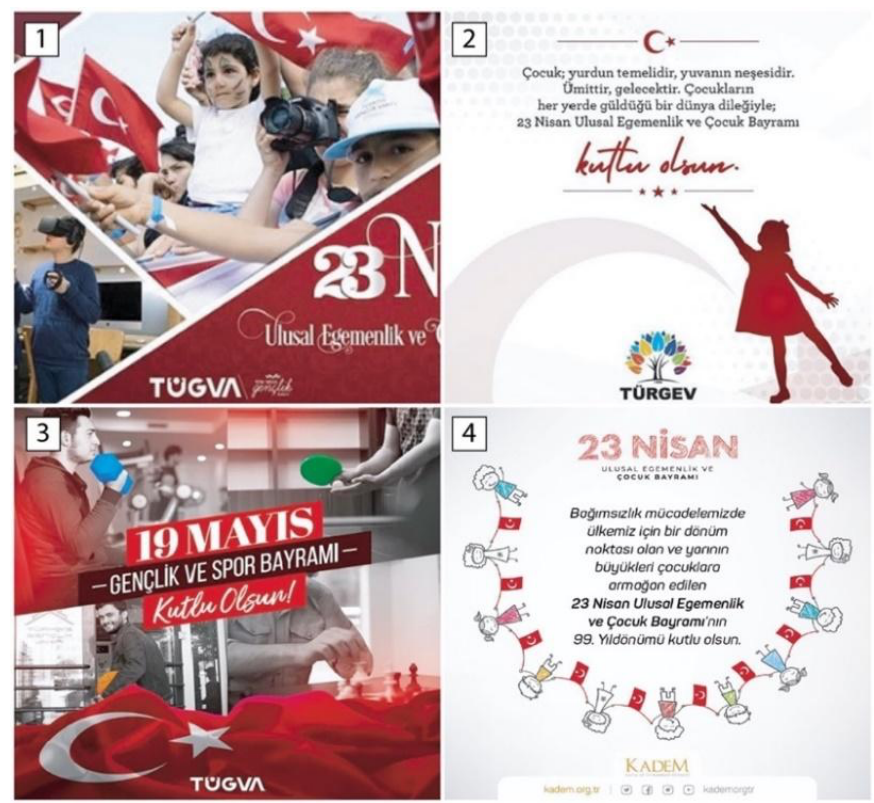

Figure 4: Instagram posts by TÜGVA, TÜRGEV, TÜGVA and KADEM

Research Article - This article was checked by iThenticate 
The analyses indicate that another one of the segments differs in terms of how the NGOs combine national and Islamic elements in their posts (Figure:5). This segment comprises two groups: the Islamic nationalist posts that honor martyrdom and child soldiers and commemorate the national days with messages of mercy and gratitude versus the posts in the other group, which encourage religious discourse with symbols such as the mosque, headscarves, and skullcaps.

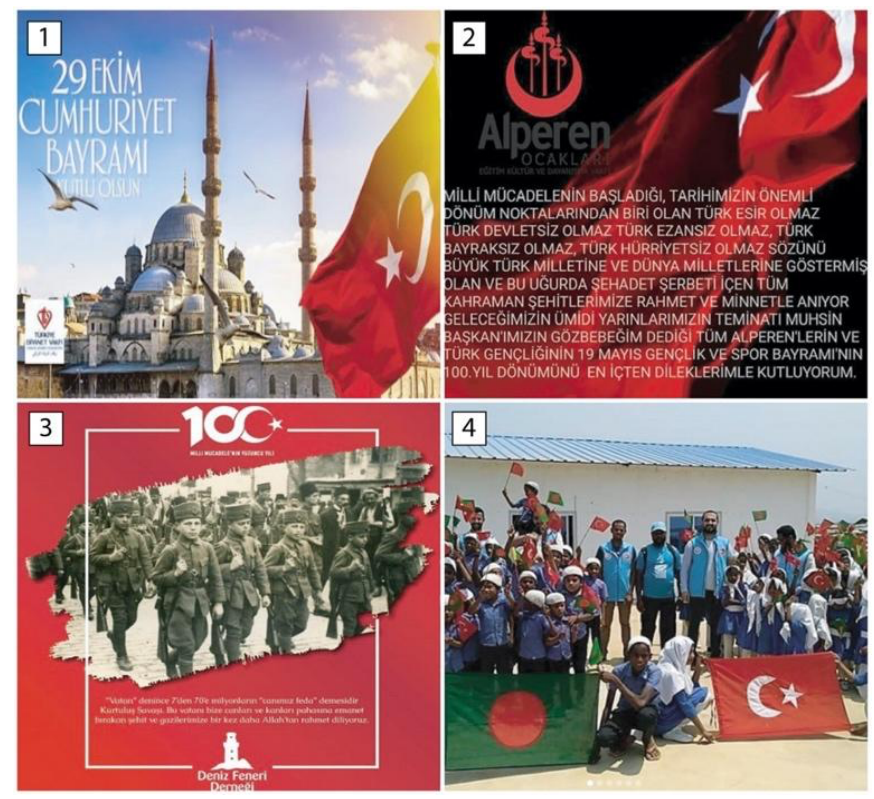

Figure 5: Instagram Postsby the religious

foundationsDiyanet Vakfı and Alperen Ocaklariand the social aid foundation Deniz Feneri

These analyses also suggest that left-wing NGOs highlight themes such as freedom, enlightenment, tolerance, and peace. Those NGOs that represent the Alawites (e.g., the Cem Foundation) promote similar themes. The liberal-conservative NGOs (like ASKON, KADEM, and MÜSIAD) emphasize independence (instead of freedom and the republic) and combine this theme with discourses of compassion and justice.

\section{Posts Specific to National Days}

In the official national historical narrative, Atatürk arrived in Samsun on May 19 and initiated the national liberation struggle. This date, which is celebrated as the Commemoration of Atatürk, is also associated with young people and sports (Table 2).

\begin{tabular}{lc}
\hline \multicolumn{1}{c}{ May 19 } & $\begin{array}{c}\text { Case } \\
\text { Frequency }\end{array}$ \\
\hline The Commemoration of Atatürk, & 17 \\
Youth and Sports Day & \\
Congratulatory Message & 11 \\
National Struggle & 9 \\
No Atatürk & 8 \\
The Flag in Background & 7 \\
Atatürk in a Suit without Hat & 7 \\
Atatürk in Kalpak and Suit & 6 \\
Star and Crescent in Numbers & 5 \\
Blue Background & 5 \\
White Background & 5 \\
\hline
\end{tabular}

Table 2: Coding Frequency of May 19

\begin{tabular}{lc}
\hline \multicolumn{1}{c}{ April 23 } & $\begin{array}{c}\text { Case } \\
\text { Frequency }\end{array}$ \\
\hline National Sovereignty and & 14 \\
Children's Day & 12 \\
Children & 11 \\
Happy Kids & 9 \\
Congratulatory Message & 8 \\
No Atatürk & 6 \\
Celebration with Kids & 4 \\
Kid Wearing Flag T-Shirt & 4 \\
Atatürk in Suit & 3 \\
Activities of The NGO & 3 \\
Children Playing Outdoor & \\
\hline
\end{tabular}

Table 3: Coding Frequency of April 23

Submit Date: 06.10.2021, Acceptance Date: 09.12.2021, DOI NO: 10.7456/11201100/009

Research Article - This article was checked by iThenticate Copyright (C) The Turkish Online Journal of Design, Art and Communication 
The above table (Table 2) shows that this national day is celebrated through Instagram posts that include the official name of the holiday and highlight themes that pertain to Atatürk, the flag, and the national struggle. (The national struggle is associated with the rise and reemergence of the Turkish nation on the world scene following the Ottoman Empire's long period of decline and dissolution.) Although the dominant themes in these posts are the national struggle and Atatürk's civil and military influence, Western and traditional identities are intertwined in the messages. The data also showed that many posts of 19th of May excluded references to Atatürk entirely. This trend repeated itself at similar frequencies in posts on other national days, which is probably a reflection of the Islamist-conservative NGOs' view that Atatürk's role in the national liberation struggle and his position in the hierarchy of national heroes is secondary. Furthermore, the NGOs often used the adopted flag figure as a background or depicted it with the crescent-star only. Also, the findings show that the NGOs prefer blue and light background tones that represent their corporate identity.

National Sovereignty and Children's Day, which is celebrated on April 23 (Table 3), is celebrated to commemorate the opening date of the Grand National Assembly of Turkey. Atatürk dedicated the day to children, and, since 1979, it has been celebrated internationally through the participation of six countries. In the codes with the highest frequency in this category symbols related to children dominate those that signify the opening of the Turkish Grand National Assembly or Atatürk. Children are often depicted as a group that would carry the revolutions of the Republic and its ideals into the future. Furthermore, children in these posts represent the official ideology and Atatürk's love and care for them. One of the most dominant trends in this day's celebrations is the NGOs' appeals for aid and the promotion of their activities on education, social aid, or healthcare for children. In other words, the NGOs that work with children use these days to promote their activities, and the national symbols remain in the background (e.g., flags in the hands of children or on t-shirts). From these findings, it is evident that April 23 has lost its international character and is now celebrated as a children's holiday mostly.

\begin{tabular}{lc}
\hline \multicolumn{1}{c}{ October 29 } & $\begin{array}{c}\text { Case } \\
\text { Frequency }\end{array}$ \\
\hline Emphasize on Republic & 15 \\
Congratulatory Messages & 14 \\
Atatürk in Suit & 10 \\
Turkish Flag as Background & 8 \\
Background in White & 7 \\
Flag Inserted in the Date & 5 \\
Atatürk With Tuxedo and Bow Tie & 4 \\
No Atatürk & 4 \\
Special Event for Republic Day & 3 \\
Silhouette of Atatürk & 3 \\
\hline
\end{tabular}

Table 4: Coding Frequency of October 29

\begin{tabular}{lc}
\hline \multicolumn{1}{c}{ August 30 } & $\begin{array}{c}\text { Case } \\
\text { Frequency }\end{array}$ \\
\hline Congratulatory Messages & 19 \\
War & 17 \\
Atatürk in Kalpak & 8 \\
Kids & 8 \\
No Atatürk & 8 \\
Atatürk Walking on War Front & 7 \\
Flag & 7 \\
Victory Message & 6 \\
Atatürk in Kalpak at War Front & 6 \\
Background White & 6 \\
\hline
\end{tabular}

Table 5: Coding Frequency of August 30

After the establishment of the Republic of Turkey on October 29, 1923, this day was declared a national holiday in a circular issued on October 29 a year later. A total of 29 of the 38 NGOs included in this study shared posts to celebrate Republic Day and Victory Day on August 30. These posts were shared more widely than any other posts, and three of the NGOs organized a special event to commemorate these days (October 29 and August 39). In the posts, the NGOs generally referred to it as Republic Day or the $96^{\text {th }}$ Anniversary of the Republic and highlighted the word "Republic." It could, therefore, be argued that the Republic is central to Turkey's national identity and that it is largely interpreted within the framework of the founding principles and symbols of the Republic and not from a civilian perspective.

In the posts on October 29, Atatürk is used more often than not and seen wearing suits, frock coats, and bow ties that emphasize his modern, secular, and progressive side. These symbols express the political and cultural vision of the Republic in terms of its position regarding tradition vs. modernity and religiosity vs. secularism.

Research Article - This article was checked by iThenticate Copyright (C) The Turkish Online Journal of Design, Art and Communication 
August 30 is the anniversary of the liberation of Western Anatolia from the Greek occupation, the success of the national struggle, and the victory of the Great Offensive that started on the morning of August 26, 1922. All the NGOs included in this study referred to this day as Victory Day, it's official name. Unlike other national holidays, the most striking aspect of the Victory Day posts was the use of cult images of Atatürk and an emphasis on his military identity. Some of NGOs posted religious messages that foregrounded Atatürk as a warrior and a Ghazi ${ }^{10}$. Most of the NGOs' messages reflected the historical meaning of the day by focusing on symbols of war, soldiers, victory, and martyrs instead of liberty and independence. At the same time, various symbols associated with Atatürk, the flag, children, and war were used in combination. The combined use of these symbols implies that citizens' sacrifices for their country are admirable, and Atatürk is a warrior and hero who saved the nation. It can be concluded that the posts that celebrate Victory Day reflect a cultic national disposition.

\section{Competing National Days}

Although the official national days remain the most frequently celebrated, the anniversary of the military coup attempt against the AKP government on July 15, 2016, is widely celebrated too (see Table 6).

\begin{tabular}{lc} 
& \\
DAYS & FRQ. \\
30 August & 29 \\
29 October & 29 \\
23 April & 25 \\
15 July Democracy and National Unity Day & 23 \\
19 May & 22 \\
10 November Ataturk's Death Anniversary & 22 \\
Battle of Galipoli & 19 \\
Battle of Malazgirt & 12 \\
Srebrenica Massacre & 9 \\
Teachers' Day & 9 \\
Conquest of Istanbul & 9 \\
Khojaly Massacre & 8 \\
Acceptance of The National Anthem & 7 \\
Battle of Sarikamish & 7 \\
Battle of Kut al-Amara & 6 \\
Anniversary of Zübeyde Hanim (Ataturks' Mother) & 6 \\
Independence Day of Azerbaijan & 5 \\
Anniversary of Eren Bulbul (Child killed by PKK) & 5 \\
Veterans' Day & 5 \\
Invasion of Cyprus & 5 \\
Anniversary of Necip Faz1l Kisakürek (Poet) & 5 \\
Anniversary of Abdulhamit II (Ottoman Sultan) & 5 \\
Anniversary of Asik Veysel (Bard) & 5 \\
Anniversary of The 1999 Earthquake & 4 \\
Anniversary of Sivas congress & 4 \\
\hline
\end{tabular}

Table 6: Most Celebrated National Days

Table 6 shows that August 30, October 29, and April 23 are the most celebrated national days. The Day, known as Democracy and National Unity Day, follows these national days, and it appears that NGOs generally recognize this new commemoration. In addition, NGOs generally commemorate the wars and military victories of the Ottoman and Seljuk eras (e.g., the Battle of Gallipoli, the Battle of Malazgirt, the Conquest of Istanbul, the Battle of Sarıkamısh, and the Kut Al Amara Battle). Mehmet Akif Ersoy (the Islamist poet and composer of the Turkish National Anthem), Necip Faz1l Kisakürek II (an Islamist poet), Abdulhamid II, and Turgut Özal (the 8th president of Turkey) appear as prominent figures. These

\footnotetext{
10 On September 19, 1921, the Assembly gave Mustafa Kemal the title of a war veteran (ghazi) and the rank of Marshall. Ghazi (plural: guzât, guzzâ, or guziy) is derived from the word "gaza" (gazve), which means to attack, fight, or to fight for the sake of religion. It is an honorary title granted to commanders and even rulers who succeed in war (see https://islamansiklopedisi.org.tr/gazi).
}

Research Article - This article was checked by iThenticate Copyright (C) The Turkish Online Journal of Design, Art and Communication 
events and figures are significant in the Islamist/conservative circles. Some national days (e.g., Khojaly Massacre and Azerbaijan Independence Day) are celebrated by supporters of Turkism and Turanism.

\section{CONCLUSION}

The study's findings suggest that various NGOs in Turkey perceive their national identity differently, which may influence their interpretation of national symbols and days. Not only do NGOs' Instagram posts represent the conservative-secular separation that marked Turkish politics for a long time; they also communicate messages and symbols that reflect nationalist, militaristic, leftist, and liberal themes, as well as issues concerning the environment, animal, and children's rights, depending on their field of interest.

It can be said that in the sharing of NGOs, three basic discourse patterns regarding national identity come to the fore in parallel with their political and ideological positions.

Kemalist Nationalism: An ideal of national identity is drawn in which Atatürk as the hero of the national struggle and a leader shaping the nation's future and his cult images intrinsic to the early republican period are at the center. On the other hand, a militarist framing structure is presented in these posts.

Right-Conservatism: While the image of Atatürk was kept in the background and the national struggle were put at the center. A youth devoted to national and moral values but has shown as the user of the latest technology.

Liberal-Kemalism: While the image of Atatürk was highlighted in these posts, his civil politician identity was emphasized stronger. Atatürk is glorified as the founder of the Democratic Republic, a progressive leader who represents Western values based on secularism, science, and rationality, and a youth that follows his ideals is idealized.

In addition to these three patterns, it can be seen that 'Islamist discourse' in which religious symbols such as mosque, martyrdom and veteran are prominent and Atatürk figures are not included at all and 'Turkism discourse' shaped around nationalism, militarism and partly Islamism, are also included in the posts on national days.

However, those segments described above are not separated from each other by sharp boundaries. In some specific cases, different segments can be intertwined, or NGO can share posts that can be included in different segments on different national days. There can be seen that there are some transitions between Kemalist nationalism and Liberal Kemalism, or between right conservatism, Islamism and Turkism. For example, in parallel with the historical meaning of national days, an NGO drawing a profile close to Kemalist nationalism in its 30th of August post, can get closer to liberal Kemalism on April 23 by using a more civilian discourse. This situation shows that national images and their meanings are not given and static, and that they can be reinterpreted according to the social, political and ideological positions of the different groups and actors that are forming the nation.

In his article named 'Nationalist Discourse in Turkey' Tanıl Bora, classified different kind of nationalism which predominates Turkish politics in 1990's under six segments such as "Official Ataturk Nationalism, Kemalist Nationalism, Liberal Nationalism, Turkic Radical Nationalism and Nationalism in Islam" (2003). According to Bora, the struggle for hegemony among these different kinds of nationalisms aims to show that they themselves are the "true" nationalism that dominates Turkish politics. He also believes that liberal nationalism and its' "dialect tends to form the dominant pattern of the Turkish nationalistic discourse". However, findings of the study show that, in Turkey, perceptions of nationalism embodying militarist Islamist, statist accents are more dominant than liberal understanding of nationalism on the verge of 2020. The thematic visual analysis of specific official national days also shows that a state-centered perspective that idealizes the nation in general seems to dominate. This situation can be conjectural in Turkey -such as lack of suitable ground for economic populism, decline of cohesion policies with the EU, and cross-border military operations coming to the agenda- after 2019.

Research Article - This article was checked by iThenticate Copyright (C) The Turkish Online Journal of Design, Art and Communication 
Until today, especially after the 1990 s, a series of research had been conducted pointing to the emerge of opposing or alternative national symbols or banal nationalisms outside of state authority (Özyürek, 2006; Caymaz, 2019). However, although the works of Özyürek and Caymaz contain rich specific examples regarding the reflections of the symbolic struggle between religious and secular sections of society in popular culture and daily life, these works are far from revealing how the meanings of national identity are symbolically constructed and how the thematic differences between these narratives emerge based on comprehensive and systematic empirical evidence. In this sense, the research, besides filling crucial gaps, offers a clue in terms of understanding how the perception of national identity has evolved in the digital media age. Social media, especially Instagram, are channels where not only global cultural trends but also national identity is produced and circulated. National identity and narratives, which were previously constructed in a state or elite-centered perspective, have evolved into a more dynamic and fragmented structure in daily life and popular culture with the social and political transformations after the 1990s. Today's social media. and digital tools provide an appropriate platform for those transformations (Szulc, 2017; Skey, 2009).

Although national days should remind a nation of its past, the NGOs included in this study are selective when it comes to choosing which days to celebrate or which historical elements to include in their messages. Especially selection between competing national days which point to the history of modern Turkey or emphasize its' imperial past seems to be quite decisive. These decisions seem to be based on their current political and ideological position, the group they represent, and their ideologies, goals and fields of activity. For example, some NGOs (case frequency is 14) prioritized national sovereignty and its embodiment, the National Assembly, on April 23, while others (case similarities are 12) emphasized only children. Similarly, on May 19, some NGOs (case similarities is 13) focused on the Commemoration of Atatürk and others on the youth (case similarities is 8) - some NGOs even altered the official name of the holiday (case similarities are 3). The NGOs' selective decisions about these national days are made largely independent of the days' historical meaning or the meanings attributed to them by the official ideology. This trend, which is also mediated by digital media, has the potential to transform national days and other national symbols into a floating and unstable signifier whose content is shaped according to the actors using them.

In this study, Atatürk appears to be the symbol that best reflects this distinction in national identities. For this reason, further studies that focus on the representation of symbols of Atatürk will provide valuable insight into national identity and social dynamics in Turkey.

\section{REFERENCES}

Açıkel, F. (2015). Post-Muhafazakarlık, Melankolik Öfke ve AKP'nin Restorasyon İdeolojisi. Birikim, 309-310.

Alkan, H. (1998). Türkiye'de İşadamı Örgütleri ve Devlet, Birikim, 114, 43-62.

Alkan M.Ö. (2001). Resmi İdeolojinin Doğuşu ve Evrimi Üzerine Bir İnceleme in Modern Türkiye'de Siyasi Düşünce Cumhuriyet'e Devreden Düşünce Mirası Tanzimat ve Meşrutiyet'in Birikimi, Cilt: I, İstanbul: İletişim Yayınevi, 377- 407.

Altan, C. (2004). Visual Narration of a Nation: Painting and National Identity in Turkey. Studies in Ethnicity and Nationalism 4. (2): 2-17.

Anderson, B. (2006). Imagined communities: Reflections on the origin and spread of nationalism. New York and London: Verso books.

Appadurai, A. (1996). Modernity at Large: Cultural Dimensions of Globalization, Minneapolis, MN: University of Minnesota Press.

Atherton, A., Elsmore, P. (2007). Structuring qualitative enquiry in management and organization research: A dialogue on the merits of using software for qualitative data analysis. Qualitative Research in Organizations and Management, 2, 62-77.

Research Article - This article was checked by iThenticate Copyright (C) The Turkish Online Journal of Design, Art and Communication 
Avedissian, K. (2016). Clerics, weightlifters, and politicians: Ramzan Kadyrov's Instagram as an official project of Chechen memory and identity production. Caucasus Survey, 4(1), 20-43.

Ayan, V, M. (2019). AKP Devrinde Medya Alemi, İstanbul: Yordam Yay.

Aydoğan, Z. (2011). Symbolic politics in action: the case of Turkey. Doctoral dissertation, San Francisco State University, 2011.

Barthes, R. (1972). Mythologies. New York: Hill and Wang.

Barthes, R. (1977). Rhetoric of the image. In Image, music, text (pp. 32-51). New York: Hill and Wang.

Baruh, L., Popescu, M. (2008). Guiding metaphors of nationalism: the Cyprus issue and the construction of Turkish national identity in online discussions. Discourse and Communication 2. (1): 79-9

Bauman, Z. (2013). Identity: Conversations with Benedetto Vecchi. New Jersey, NJ: John Wiley \& Sons.

Berger, J. (1972). Ways of Seeing. London: British Broadcasting Association and Penguin.

Bazeley, P. (2013). Qualitative Data Analysis: Practical Strategies. London; Thousand Oaks, Calif: SAGE.

Billig, M. (2010). Banal nationalism. SAGE Publications Ltd.

Bora, T. (2003). Nationalist Discourses in Turkey, South Atlantic Quarterly 102. (2-3): 433-451.

Bozdoğan, S. (1997). The Predicament of Modernism in Turkish Architectural Culture. In Bozdoğan, Sibel and Reşat Kasaba (Ed.), Rethinking Modernity and National Identity in Turkey. Seattle: University of Washington Press.

Canbolat, İ. (2002). Küreselleşen Dünya ve Türkiye, Bursa: Vipaş Yayınları.

Castells, M. (1997). The Power of Identity, The Information Age: Economy, Society and Culture, Vol. II, Cambridge, MA and Oxford: Blackwell.

Castells, M. (2016). İletişimin Gücü, İstanbul: İstanbul Bilgi Üniversitesi Yayınları.

Caymaz, B. (2019). The Construction and Re-construction of the civil religion around the cult of Atatürk. Middle Eastern Studies, 55. (6): 945-957.

Cohen, A., P. (2011). The symbolic Construction of Community, London and New York: Taylor \& Francis Group.

Coleman, R. (2010). Framing the pictures in our heads: Exploring the framing and agenda-setting effects of visual images in D'Angelo, Paul and Jim A. Kuypers (Ed.), Doing news framing analysis: Empirical Theoretical Perspectives, New York: Routledge. 233-262.

Cizre-Sakallığlu, Ü., Çınar, M. (2003). Turkey 2002: Kemalism, Islamism, and politics in the light of the February 28 process. The South Atlantic Quarterly 102. (2): 309-332

Edensor, T. (2002). National identity, popular culture and everyday life. Oxford and New York: Berg.

Geisler, M. E. (2009). The calendar conundrum: national days as unstable signifiers. In McCrone, David and Gayle McPherson, (Ed.), National Days, Palgrave Macmillan, London, 10-25.

Glyptis, L. (2008). Living up to the father: The national identity prescriptions of remembering Atatürk; his homes, his grave, his temple. National Identities 10. (4): 353-372.

Gümüş̧̧ü, Ş. (2010). Class, Status and Party: The Changing Face of Political Islam in Turkey and Egypt. Comparative Political Studies. 43. (7): 835-861.

Gündüz, U., and Erdem, B. K. (2017). The concept of virtual nationalism in the digital age: Social media perspectives of Turkey. Communication Today, 8(2), 18-29. 
Hall, S., Du Gay, P. (ed.). (1996). Questions of cultural identity, Sage Publications, London, 1996.

Hansen, A., Machin. D. (2013). Media and Communication Research Methods: An Introduction, Basingstoke: Palgrave Macmillan.

Hart, K, (1999). Images and Aftermaths: The Use and Contextualization of Ataturk Imagery in Political Debates in Turkey. PoLAR, 22. (66).

Hobsbawm, E., Ranger, T. (2000). The invention of tradition. Cambridge University Press.

Hofstede, G. (1991). Cultures and Organizations: Software of the Mind. New York: McGraw-Hill.

Houston, C, (2005). Provocations of the built environment: animating cities in Turkey as Kemalist. Political Geography 24. (1):101-119.

Iedema, R. (2001). Analysing film and television: a social semiotic account of Hospital: An Unhealthy Business. In T. van Leeuwen \& C. Jewitt (Eds.), Handbook of VisualAnalysis (pp. 183-206). London: Sage.

Jewitt, C., Oyama, R. (2001). Visual meaning: a social semiotic approach. In T. van Leeuwen, C. Jewitt (Eds.), Handbook of VisualAnalysis (pp. 134-156). London: Sage

Keyman, F. E. (1997). Globalization, State and Identity/Difference, New Jersey: Humanities Press, 193-206.

Keyman, F, E. (2007). Modernity, Secularism and Islam: The case of Turkey. Theory, Culture and Society 24. (2): 215-234.

Kezer, Z. (2009). An imaginable community: the material culture of nation-building in early republican Turkey. Environment and Planning D. Society and Space 27. (3):508-530.

Khatib, L. (2013). Image politics in the middle east: The role of the visual in political struggle. London: I.B Tauris.

Kongar, E. (2013). 21. Yüzyılda Türkiye. Remzi Kitabevi, İstanbul.

Köse, A. and Y1lmaz, M. (2012). Flagging Turkishness: The Reproduction of Banal Nationalism in the Turkish press. Nationalities Papers 40. (6):909-925.

Laclau, E. (2005). On populist reason. London: Verso.

LaPan, C. (2013). Review of QDA Miner. Social Science Computer Review, 31(6), 774-778.

Mangabeira, W. C., Lee, R. M., Fielding, N. G. (2004). Computers and qualitative research: Adoption, use, and representation. Social Science Computer Review, 22, 167-178.

Mango, A. (2002). Atatürk: The Biography of the Founder of Modern Turkey. Woodstock, N.Y.: Overlook Press.

Manovich, L. (2017). Instagram and Contemporary Image, http://manovich.net/content/04projects/157-instagram-and-contemporary-image/instagram_book_manovich_2017.pdf, Access Date: 29.10.2021.

Mardin, Ş. (1973), Center-Periphery relations: A key to Turkish Politics, Daedalus 102. (1):169-90.

Marcella-Hood, M. (2019). Exploring contemporary illustrations of Scottish identity through a study of Scottish fashion influencers on Instagram. Scottish Affairs, 28(4), 367-394.

McCrone, D. and McPherson, G. (2009), National Days, Palgrave Macmillan, London.

Meeker, M. (1997). Once There Was, Once There Wasn't: National Monuments and Interpersonal Exchange. in Bozdoğan, Sibel and Reşat Kasaba (Ed.), Rethinking Modernity and National Identity in Turkey. Seattle: University of Washington Press. 
Mills, K. (2002). Cybernations: Identity, self-determination, democracy and the" Internet effect" in the emerging information order. Global society, 16(1), 69-87.

Ongur, H. O. (2015). Identifying Ottomanisms: The discursive evolution of Ottoman pasts in the Turkish presents. Middle Eastern Studies 51. (3):416-432.

Ökten, N. (2007). An Endless Death and an Eternal Mourning, The Politics of Public Memory in Turkey, in Özyürek, Esra. (Ed.). The politics of public memory in Turkey. New York: Syracuse University Press.

Öniş, Z., Türem, U. (2001). Business, Globalization and Democracy: A Comparative Analysis of Turkish Business Associations, Turkish Studies 2. (2): 94-120.

Özyürek, E. (2006). Nostalgia for The Modern: State Secularism and Everyday Politics in Turkey. Duke University Press.

Özyürek, E. (2004). Miniaturizing Atatürk Privatization of Sate Imagery and Ideology in Turkey. American Ethnologist 31. (3): 374-391.

Poster, M. (1999). National identities and communications technologies. The Information Society, 15(4), 235-240.

Rose G. (2016). Visual methodologies: An introduction to Researching with Visual Materials, 4th edn. London: Sage.

Skey, M. (2009). The national in Everyday Life: A Critical Engagement with Michael Billig's Thesis of Banal Nationalism. The Sociological Review 57. (2):331-346.

Smith, A. D. (1991). National identity. (Vol. 11). Reno: University of Nevada Press.

Szulc, L. (2017). Banal Nationalism in The Internet Age: Rethinking the Relationship Between Nations, Nationalisms and The Media. In Skey, Michael and Marco Antonsich (eds.) Everyday Nationhood: Theorising Culture, Identity and Belonging after Banal Nationalism. London: Palgrave Macmillan, 5374 .

Toprak, B., Çarkoğlu, A. (2006). Religion, Society and Politics in a Changing Turkey. İstanbul: TESEV. Türk, E., B. (2018). Kalpak as A National Image in Turkish Novel. Gazi Türkiyat, 22: 159-178.

Wodak, R. (2009). Discursive construction of national identity. Edinburgh: Edinburgh University Press. Yilmaz, İ., Caman, M. E., Bashirov, G. (2020). How an Islamist party managed to legitimate its authoritarianization in the eyes of the secularist opposition: the case of Turkey. Democratization, 27. (2): $265-282$

Yumul, A., Özkırımlı, U. (2000). Reproducing The Nation: Banal Nationalism'in the Turkish Press. Media, Culture and Society 22. (6):787-804. 